\title{
Molecular Epidemiology of the Human Group A Rotavirus in the Paraná State, Brazil
}

\author{
Jucélia Stadinicki dos Santos ${ }^{1}$, Alice Fernandes Alfieri ${ }^{2}$, José Paulo Gagliardi Leite ${ }^{3}$, Irene \\ Skraba $^{4}$ and Amauri Alcindo Alfieri ${ }^{2 *}$ \\ ${ }^{1}$ Programa de Pós-graduação em Microbiologia, Parasitologia e Patologia; Universidade Federal do Paraná - \\ UFPR; Curitiba - PR - Brasil. ${ }^{2}$ Universidade Estadual de Londrina - UEL; alfieri@ uel.br; Londrina - PR - Brasil. \\ ${ }^{3}$ Instituto Oswaldo Cruz - FIOCRUZ; Rio de Janeiro - RJ - Brasil. ${ }^{4}$ Laboratório Central do Estado do Paraná - \\ LACEN-PR; Curitiba - PR - Brasil.
}

\begin{abstract}
From January/2000 to December/2003, 550 diarrheic fecal samples from the children and adults were collected in several geographical regions of Paraná State, Brazil. The enzyme immunoassay showed 120 (21.8\%) samples positive for the group A rotaviruses. One hundred and fourteen samples were genotyped by multiplex-nested-PCR assay. The highest frequency $(77.5 \%)$ of the positive samples $(n=93)$ was observed in the children under 5 years old. Rotavirus diarrhea was more frequent in the cold and dry seasons of the four evaluated years. The most frequent genotypes were: G1 (50.9\%), G4 (9.6\%), G9 (7.0\%), G2 (1.7\%), G3 (0.9\%), P[8] (71.9\%), and P[4] (3.5\%). The $P[8] G 1(46.5 \%)$ and P[8]G4 (9.6\%) were the main combinations found to $P$ and $G$ genotypes. The mixed infections, characterized by the rotaviruses with more than one genotype $G$ or $P$, and nontypeable rotavirus were observed in $8.8,3.5$, and $16.7 \%$ of the samples, respectively. The identification of the G9 genotype in the rotavirus strains tested along the four years of studies ratifies the emergency of this genotype also in Paraná State, South region of Brazil, as the worldwide.
\end{abstract}

Key words: Diarrhea, Rotavirus, Diagnostic, PAGE, RT-PCR, Genotypes

\section{INTRODUCTION}

The acute infectious diarrhea is the most common cause of morbidity and mortality among the young children in the developing countries, accounting for almost one billion illnesses and between 2.5 and 3.2 million deaths annually (Kosek et al., 2003). The rotaviruses are the single most important etiological agent of severe diarrheal illness of the infants and young children worldwide. Each year, the rotaviruses cause approximately 111 million episodes of the gastroenteritis requiring only home care, 25 million clinical visits, two million hospitalizations, and 352,000 - 592,000 deaths in the children of less than five years old worldwide. The children in the developing countries account for $82 \%$ of the rotavirus deaths (Parashar et al., 2003).

The rotaviruses are members of the Reoviridae family and the complete virus particle is often described as smooth, measures about $100 \mathrm{~nm}$ in diameter and possesses a triple-layered icosahedral protein capsid composed of an outer layer (VP7 and VP4), an intermediate layer (VP6), and an inner core layer (VP2). The viral genome consists of 11 double-stranded RNA (dsRNA) (Pesavento

\footnotetext{
${ }^{*}$ Author for correspondence
} 
et al., 2003). Group and subgroup specificities are mediated mainly by VP6, which is the major intermediate capsid protein. To date, seven groups, designated as A-G, have been distinguished in the rotavirus strains from the humans and animals. The groups $\mathrm{A}, \mathrm{B}$, and $\mathrm{C}$ have been described in the humans and among them the group $\mathrm{A}$ is the most common cause of the acute gastroenteritis in the young children (Kapikian et al., 2001).

The two outer capsid proteins, VP7 and VP4, are the basis of a binary rotaviruses classification system in the $G$ (glycoprotein) and $P$ (protease sensitive) types, respectively. So far, 15 different $\mathrm{G}$ and 25 different $\mathrm{P}$ genotypes have been reported (Rao et al., 2000, Rahman et al., 2005). Because the VP4 and VP7 are coded by different RNA segments, various combinations of the $G$ and $P$ types can be observed. Most $G$ types were serologically confirmed as serotypes, but for the $\mathrm{P}$ types due to the lack of appropriate antibody reagents, a dual $P$ typing system has been used. The G types G1, G2, G3, and G4 constitute more than $80 \%$ of all the human $G$ genotypes detected worldwide. In humans, $\mathrm{P}[8]$ is the most common $\mathrm{P}$ genotype, followed by $\mathrm{P}[4]$ and P[6]. Studies of the genotyping have indicated that the P[8]G1, $\mathrm{P}[4] \mathrm{G} 2, \mathrm{P}[8] \mathrm{G} 3$, and P[8]G4 genotypes are the most frequently observed, followed by the P[8]G9 and P[6]G9 (Santos and Hoshino, 2005).

While the rates of the morbidity related to the rotavirus diarrhea are similar in both the industrialized and developing countries, the disease is often severe and fatal among the infants and young children living in the developing countries, where inadequate sanitation conditions and mostly malnutrition may be an additional hazard (Kapikian et al., 2001). The success of a prevention program based on the use of the vaccines is dependent of the previous knowledge of the most frequent rotavirus genotypes found in the population, particularly in the developing regions of the world.

The aim of this study was to characterize the genotypes $\mathrm{P}$ and $\mathrm{G}$ of the group $\mathrm{A}$ rotavirus identified in the fecal samples from the patients with acute diarrhea in the Paraná State, Brazil.

\section{MATERIALS AND METHODS}

\section{Clinical samples and viral detection}

From January 2000 to December 2003 a total of 550 fecal samples were collected from the children and adults with acute gastroenteritis in 38 counties of the Paraná State, Brazil. All the fecal specimens were sent to the Public Health Laboratory (LACEN-PR) for the rotavirus diagnosis. Only one fecal sample was collected per diarrhea episode. The fecal suspensions were prepared by dilution of the fecal samples $(10-20 \% \mathrm{w} / \mathrm{v})$ in phosphatebuffered saline (PBS), pH $7.2(137 \mathrm{mM} \mathrm{NaCl} ; 3$

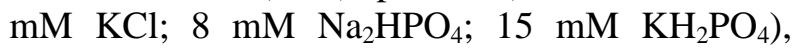
followed by mixing and clarification at $2000 \times \mathrm{g}$ for $10 \mathrm{~min}$ at $4^{\circ} \mathrm{C}$. The fecal suspensions were screened using an enzyme immunoassay (ELISA) for group A rotavirus and adenovirus detection (EIARA) (Pereira et al., 1985), supplied by BioManguinhos, Oswaldo Cruz Fundation, Rio de Janeiro, Brazil, the following manufacturer recommendations. For the PAGE analysis and P/G genotypes detection only group A rotavirus positive fecal samples by ELISA test were used.

\section{RNA Extraction}

The fecal suspensions $(10 \% \mathrm{w} / \mathrm{v})$ of semi-solid feces or a $50 \%(\mathrm{v} / \mathrm{v})$ suspension of the liquid feces were prepared in Tris-calcium buffer $\mathrm{pH} 7.2$ $\left(0.01 \mathrm{M}\right.$ Tris- $\left.\mathrm{HCl} ; 0.0015 \mathrm{M} \mathrm{Ca}^{2+}\right)$. The suspensions were centrifuged for $10 \mathrm{~min}$ at $1200 \mathrm{x} \mathrm{g}$ and the supernatants were stored at $-20^{\circ} \mathrm{C}$. Aliquots of 450 $\mu \mathrm{l}$ of each fecal suspension were treated with SDS $10 \%$ for $20 \mathrm{~min}$ at $56^{\circ} \mathrm{C}$. For the dsRNA extraction the silica/guanidine isothiocyanate method was used (Boom et al., 1990), adapted to the use of one initial step of phenol-chloroform-isoamyl alcohol (Alfieri et al., 2004).

\section{PAGE}

The silver-stained polyacrylamide gel electrophoresis (PAGE) was performed as previously described (Herring et al., 1982, Pereira et al., 1983).

\section{RT-PCR}

The reverse transcription (RT) reaction was performed with 2 to $7 \mu \mathrm{l}$ of extracted dsRNA and 20 pmol of the consensual primers to the VP4 (4con3 and 4con2) or VP7 (9con1 and 9con2) genes (Gentsch et al., 1992, Das et al., 1994) that 
were denatured at $97^{\circ} \mathrm{C}$ for $5 \mathrm{~min}$ and quickly chilled in the ice for $2 \mathrm{~min}$. Subsequently, the RT mix containing $1 \mathrm{x}$ PCR buffer $(20 \mathrm{mM}$ Tris- $\mathrm{HCl}$ $\mathrm{pH} 8.4,50 \mathrm{mM} \mathrm{KCl}), 5 \mathrm{mM} \mathrm{MgCl}_{2}, 0.5 \mathrm{mM}$ of each dNTP (Invitrogen, USA), $30 \mathrm{U}^{\text {SuperScript }}{ }^{\mathrm{TM}}$ II RT (Invitrogen, USA) and the ultrapure sterile water to a final volume of $20 \mu \mathrm{l}$ were added, incubated at $42^{\circ} \mathrm{C}$ for $45 \mathrm{~min}$ and then followed by inactivation at $95^{\circ} \mathrm{C}$ for $5 \mathrm{~min}$.

For the PCR reaction, the PCR mix solution containing $20 \mathrm{pmol}$ of each consensual primer to the VP4 or VP7 gene, $0.4 \mathrm{mM}$ of each dNTP, $1 \mathrm{x}$ PCR buffer, $1.25 \mathrm{U}$ of Platinum ${ }^{\circledR}$ Taq DNA polymerase (Invitrogen, USA) and ultrapure sterile water to a final volume of $25 \mu \mathrm{l}$ was added to the cDNA tubes. The reaction was performed in a thermocycler (PTC-200, MJ Research Co. Water Town, MA, USA) with the following time and temperature conditions: one step of $3 \mathrm{~min} / 94^{\circ} \mathrm{C}$; followed by 40 cycles of $45 \mathrm{~s} / 94^{\circ} \mathrm{C}, 45 \mathrm{~s} / 45^{\circ} \mathrm{C}, 1$ $\min / 72^{\circ} \mathrm{C}$ and a final cycle of $10 \mathrm{~min} / 72^{\circ} \mathrm{C}$.

\section{Typing by Multiplex Nested PCR}

The RT-PCR product $(1 \mu$ at dilutions of $1: 10$, $1: 100$ or $1: 1000$ ) was used as the template for a second amplification round. This product, together with 20 pmol consensual primer 9con 1 and a pool of specifics VP7 primers for the $G$ typing in the same concentration, or consensual primer $4 \operatorname{con} 3$ and a pool of specifics VP4 primers for the $\mathrm{P}$ typing, were denatured at $97^{\circ} \mathrm{C}$ for $5 \mathrm{~min}$ and quickly chilled in the ice for $2 \mathrm{~min}$. The specific primers used for the G typing were a pool of G1, G2, G3, G4 (Das et al., 1994) and G5 (Gouvea et al., 1994b); a pool of G8, G10 (Gouvea et al., 1994b), G9 (Das et al., 1994), and a pool of G6 and G11 (Gouvea et al., 1994b). For the P typing the primers $\mathrm{P}[4], \mathrm{P}[6], \mathrm{P}[8]$ and $\mathrm{P}[9]$ were used (Gentsch et al., 1992). For the detection of the P[1] genotype were used a previously described primer (Gouvea et al., 1994a) together with the 4con2 consensual primer.

The N-PCR mix containing $2 \mathrm{mM} \mathrm{MgCl}_{2}, 0.4 \mathrm{mM}$ of each dNTP, 1x PCR buffer, 1.25 $\mathrm{U}$ of Platinum $^{\circledR} T a q$ DNA polymerase and ultrapure sterile water to a final volume of $24 \mu \mathrm{l}$ was added in each sample. The Nested PCR consisted of 1 step at $94^{\circ} \mathrm{C} / 3 \mathrm{~min} ; 40$ cycles of $94^{\circ} \mathrm{C} / 1 \mathrm{~min}$, $55^{\circ} \mathrm{C} / 2 \mathrm{~min}$ and $72^{\circ} \mathrm{C} / 1 \mathrm{~min}$, followed by a final step at $72^{\circ} \mathrm{C} / 10 \mathrm{~min}$.
Analysis of RT-PCR and Multiplex Nested PCR The products were analyzed by the electrophoresis in a 1.5\% (RT-PCR) and 2\% (Multiplex Nested PCR) agarose gel in TBE buffer pH $8.4(89 \mathrm{mM}$ Tris; $89 \mathrm{mM}$ boric acid; $2 \mathrm{mM}$ EDTA), ethidium bromide $(0.5 \mu \mathrm{g} / \mathrm{ml})$ stained and visualized under UV light.

\section{Statistical analysis}

$\chi^{2}$ test was used to analyze the data obtained to the age group and seasonal distribution of the group A rotavirus infection. A value of $p<0.05$ was considered statistically significant.

\section{RESULTS}

A total of 120 (21.8\%) diarrheic fecal samples were positive for the group A rotavirus by the EIARA. Of these, $114(95.0 \%)$ positive samples had enough amounts to be used in the genotyping analysis. According to the age group, it was observed that rotavirus was detected with significantly $\left(\chi^{2}=28.07 \quad p<0.0001\right)$ higher frequency in the children up to five years old. The positive rates of 27.6 and $30.1 \%$ were detected in children with $0-2$, and 2-5 years old (Table 1), respectively.

The detection rates of the rotavirus varied with the month of the sample collection throughout the four years (2000-2003) studied. A significant $\left(\chi^{2}=\right.$ $119.57 p<0.0001)$ difference was observed in the frequency of the rotavirus detection from July to September showing the rotaviruses seasonality. In this study, 114 (95\%) of 120 positive samples were characterized by the PAGE and showed the characteristic 4-2-3-2 pattern of the group A rotavirus. Most of them exhibited a long $10^{\text {th }}$ and $11^{\text {th }}$ RNA segment pattern, with the exception of one strain with a short profile. The rotaviruses from $85(74.6 \%)$ fecal specimens were typed for at least one of the P (VP4) and G (VP7) types; 10 $(8.8 \%)$ samples were genotyping only to $\mathrm{P}$ or $\mathrm{G}$ type and $19(16.7 \%)$ samples were nontypable for both $P$ and $G$ types. The combinations of the $G$ and $\mathrm{P}$ types most frequently found were $\mathrm{P}[8] \mathrm{G} 1$ (46.5\%) and P[8]G4 (9.6\%). However, a variety of the combinations, such as a single $\mathrm{P}$ genotype with two or three $G$ genotypes, and two $P$ genotypes with one $G$ genotype, were also observed. The overall results of RT-PCR genotyping are summarized in Table 2. 
Table 1 - Frequency of the group A rotavirus detected by enzyme immunoassay in fecal samples from humans beings with acute diarrhea, distributed according to the age group. Paraná State, Brazil, 2000-2003.

\begin{tabular}{lcc}
\hline $\begin{array}{l}\text { Age group } \\
\text { (years) }\end{array}$ & $\begin{array}{c}\mathbf{N}^{\circ} \text { tested } \\
\text { samples }\end{array}$ & $\begin{array}{c}\mathbf{N}^{\circ} \text { positives } \\
(\%)\end{array}$ \\
\hline $0<1$ & 101 & $25(24.7)$ \\
$1<2$ & 102 & $31(30.4)$ \\
$2<3$ & 61 & $20(32.8)$ \\
$3<4$ & 43 & $13(30.2)$ \\
$4<5$ & 19 & $4(21.0)$ \\
$5<15$ & 62 & $13(21.0)$ \\
$\geq 15$ & 131 & $8(6.1)$ \\
ND* & 31 & $6(19.3)$ \\
\hline Total & 550 & $120(21.8)$ \\
\hline ND (not registered date) & &
\end{tabular}

Table 2 - Genotypes G (VP7) and P (VP4) of the group A rotavirus, identified by multiplex-nested-PCR assay, in fecal samples ( $n=114)$ of children and adults with acute diarrhea. Paraná State, Brazil, 2000-2003.

\begin{tabular}{|c|c|c|c|c|c|}
\hline \multirow{2}{*}{ Genotype } & \multicolumn{4}{|c|}{$\mathrm{N}^{\circ}$ of specimens (\%) } & \multirow{2}{*}{ Total } \\
\hline & $\mathbf{P}[4]$ & $\mathbf{P}[8]$ & $P[4]+P[8]$ & $P$ untypeable & \\
\hline G1 & - & $53(46.5)$ & $4(3.5)$ & $1(0.9)$ & $58(50.9)$ \\
\hline $\mathrm{G} 2$ & $2(1.7)$ & - & - & - & $2(1.7)$ \\
\hline G3 & - & $1(0.9)$ & - & - & $1(0.9)$ \\
\hline G4 & - & $11(9.6)$ & - & - & $11(9.6)$ \\
\hline G9 & - & $4(3.5)$ & - & $4(3.5)$ & $8(7.0)$ \\
\hline $\mathrm{G} 1+\mathrm{G} 4$ & - & $4(3.5)$ & - & - & $4(3.5)$ \\
\hline $\mathrm{G} 1+\mathrm{G} 9$ & $1(0.9)$ & $2(1.7)$ & - & - & $3(2.6)$ \\
\hline $\mathrm{G} 1+\mathrm{G} 2+\mathrm{G} 4$ & - & $1(0.9)$ & - & - & $1(0.9)$ \\
\hline $\mathrm{G} 1+\mathrm{G} 4+\mathrm{G} 9$ & - & $1(0.9)$ & - & - & $1(0.9)$ \\
\hline $\mathrm{G} 4+\mathrm{G} 9$ & - & $1(0.9)$ & - & - & $1(0.9)$ \\
\hline G untypeable & $1(0.9)$ & $4(3.5)$ & - & $19(16.7)$ & $24(21.1)$ \\
\hline Total & $4(3.5)$ & $82(71.9)$ & $4(3.5)$ & $24(21.1)$ & $114(100.0)$ \\
\hline
\end{tabular}

\section{DISCUSSION}

The occurrence of the group A rotavirus was observed, as expected, mainly among the infants and young children up to five years old $(77.5 \%)$. One positive case of the rotavirus was observed in a newborn with six days of age, and in this case, the genotype was nontypeable, remained to be elucidated. The prevalence of the rotavirus infection in the neonates has not been systemically examined, but high infection rates were documented in the newborns in India's hospital, where these infections were caused by the unusual strains of the rotavirus (Cicirello et al., 1994). In the adults, one positive case of infection by the rotavirus was observed in the elderly. The 
epidemiological studies show that, the group A rotavirus infection in the adults are usually subclinical, but occasionally, cause illness in the parents of children with the rotavirus diarrhea, and immunocompromised and/or elderly patients (Parashar et al., 1998). In this investigation, the high number of diarrheic fecal specimens directed for the diagnosis of the rotavirus in the adults patients, could be attributed to non-group A rotavirus or to other pathogens not evaluated.

The pattern of the seasonal distribution of the rotaviruses could detect a major peak of the rotaviruses during the coldest and driest months of each year, mainly between July and September. In the developed countries, the rotaviruses display a seasonal pattern of the infection, with epidemic peaks occurring in the coldest and driest months of each year. This usual seasonal pattern of the rotavirus infection observed in the countries with the temperate climates does not occur uniformly in others (Kapikian et al., 2001). In Brazil, have been different frequencies of the rotavirus detection, due to the range of the climatic factors (Pereira et al., 1993). In several studies, the seasonality of the rotavirus cases could be correlated with the low relative atmospheric air humidity (Sattar et al., 1984, Coluchi et al., 2002, Cardoso et al., 2003). The Brazilian South region (Paraná State) has well defined season and may represent the same seasonal pattern observed in the countries with temperate climates.

The only rotavirus strain with a short electropherotype profile detected by the PAGE in this study showed P[4]G2 genotype. This genotype was previously related with the short profile in other studies (Mascarenhas et al., 1997, Coluchi et al., 2002).

The rotaviruses are generally species-specific, but cross-species transmission is possible. Several studies have found the evidence of in vivo reassortment between different human rotavirus strains and also between the animal and human strains (Cunliffe et al., 1999). The rotavirus genotypes commonly found in animals, as G3, G5, G6, G8, G9, G10, and P[6], P[9], P[11], P[14], and $\mathrm{P}[19]$ have been recorded in the human population throughout the world (Desselberger, 2000). The G5 genotype is a common porcine genotype that has been described as the infection agents for the humans in several studies, including in Brazil (Alfieri et al., 1996, Villena et al., 2003). However, no G5 or other animal genotypes were observed in this investigation.
For the $G$ genotypes, the $G 1$ was found as predominant. This genotype was present as the only $\mathrm{G}$ genotype in $50.9 \%$ of the diarrheic fecal specimens and as single and mixed infection in $58.8 \%$ of the analyzed samples. The second most frequent $\mathrm{G}$ genotype was the G4, present in $15.8 \%$ of the evaluated samples. Several studies shown that the G1, G2, G3, and G4 account for more that $80 \%$ of the global human rotavirus strains. In some geographical regions, other $\mathrm{G}$ types may be of epidemiological important (Santos and Hoshino, 2005). In Mexico, the G2 serotype was associated with $92 \%$ of the gastroenteritis in the children (Gonzales-Ioza et al., 2000). In North region of Brazil, the G1 (50\%) and G2 (30\%) genotypes were prevalent in a study carried out between 1983 and 1985 (Linhares et al., 1988), and a subsequent study showed the following frequencies: G1 (65\%), G2 (30\%), G3 (1.2\%), G4 (4.6\%) and G9 (1.2\%) (Linhares et al., 1996). Extensive study develop by Pereira et al. (1993) demonstrated that the G1, G2, G3, G4 had frequencies of $42,24,16$, and $18 \%$, respectively. Worldwide, the G genotypes have shown clear floating in the relative frequencies to the predominant genotypes, and this diversity in different countries confirms the importance of continuous monitoring of the human rotavirus strains identified around the world.

The G9 was the third most frequent genotype and was found in many counties of different geographical regions of Paraná State during the four years (2000-2003) of study. This result ratified the wide geographical distribution of the G9 genotype detected since 1995 in several countries, including Brazil, and reinforced the possibility that this genotype could represent a fifth globally important genotype (Santos and Hoshino, 2005). Perhaps this genotype is now replacing G5 genotype in Brazil. The occurrence of the mixed infections to the $G$ types observed in the study confirmed the indication that in the developing countries the scale of the mixed infections was more evident (Leite et al., 1996, Jain et al., 2001).

The diversity for the $\mathrm{P}$ types was less than that found for the $G$ genotypes. The predominant genotype was the P[8] followed by P[4]. No other $\mathrm{P}$ genotype was detected in the fecal samples included in this study. In several studies, the same results have been frequently detected worldwide (Fang et al., 2002, Santos and Hoshino, 2005). The most frequent $\mathrm{P}$ and $\mathrm{G}$ genotypes combinations found in the rotavirus positive fecal samples were 
$\mathrm{P}[8] \mathrm{G} 1$ and $\mathrm{P}[8] \mathrm{G} 4$ as single and/or mixed infection. In a global scale, these genotypes are commonly found in rotaviruses that infect the children world wide (Gentsch et al., 1996). However, the $\mathrm{P}[4]$ and $\mathrm{P}[8]$ in combination with the $\mathrm{G} 2$ genotype in 50 and $28.6 \%$ of the rotavirus positive fecal samples, respectively were the most frequent genotypes found in a survey carried out with the pediatric patients in Belém, Pará, North region of Brazil, between 1992-1993 (Mascarenhas et al., 1999). These results suggested that, the rotavirus $\mathrm{P}$ and G-types seemed to co-circulate within the same country at prevalence rates that could differ significantly from one region to another. Moreover, it seemed unlikely that differences in the P-types showed in these studies could be attributed to the source (community or hospital acquired infection) of the rotavirus. The $\mathrm{P}[6]$ genotype in association with the $G$ genotypes have been mentioned in several studies (Gentsch et al., 1996, Villena et al., 2003), but none of them was observed in this work. Although a mixed infection of $\mathrm{P}[4]+\mathrm{P}[8]$ genotypes was found in four samples, none of these showed simultaneous G-type mixtures, while the G-type mixed infection, found in 10 samples, also did not show simultaneous P-type mixtures. These results needed further confirmation since they could represent the nontypeable $G$ or P types coinfecting the same patient. Another possible explanation for these results was the presence of the coinfections with the rotavirus strains sharing the identical $\mathrm{G}$ or $\mathrm{P}$ types. The rotavirus strains nontypeable for the $\mathrm{P}$ and/or $\mathrm{G}$ genotypes could be related to the failure of the genotyping due the presence of the other genes not investigated in this survey, or with the necessity to use of the degenerate primers to improve the results.

The large-scale adoption of the rotavirus vaccination program would increase the importance of the rotavirus strains surveillance in the children with acute gastroenteritis. Although the homotypic responses to the $G$ serotypes seem to predominate, numerous studies involving the humans and other animal models have shown that: i) the heterotypic responses are commonly elicited, even after primary infection, and ii) the maternal antibodies are important to protect against severe gastroenteritis in the neonates and infants (Ray and Kelkar, 2004). Particular attention should be focused on the characterization of the P-types, mainly because the studies supported the hypothesis that the VP4 could be more effective in producing the virus-specific serum neutralizing antibodies during the natural infection (Matsui et al., 1989). As several studies have demonstrated, increasing rate of the G9 genotype identification, highlighted the possibility that new emerging serotypes would be important for vaccination strategies.

The combination of the genotypes observed in this study and in several other studies showed that the rotavirus diversity exhibited not only a geographical but also a temporal pattern. The monitoring of the rotaviruses worldwide should contribute to the success of prevention programs, mainly in the developing countries, where the cases of the acute gastroenteritis associated with the sub-nutrition are frequently responsible for a great number of hospitalizations and many deaths.

\section{ACKNOWLEDGMENTS}

The authors wish to thanks to the Central Laboratory of Public Health / Paraná State (LACEN) by supplying the clinical samples and to the SIMEPAR by the meteorological data.

This work was supported with the financial resources of the following Brazilians agencies: CNPq, CAPES and Fundação Araucária (FAP/PR). Alfieri, A.A., Alfieri, A.F., and Leite, J.P.G. are recipient of CNPq fellowship.

\section{RESUMO}

No período de janeiro de 2000 a dezembro de 2003 foram colhidas, em várias regiões geográficas do Estado do Paraná, 550 amostras fecais de crianças e adultos com quadro clínico de diarréia aguda. Por meio de ensaio imunoenzimático comercial, 120 (21,8\%) amostras foram positivas para o rotavírus grupo A. Dessas, 114 amostras foram genotipadas por meio da multiplex-nested-PCR. A maior freqüência $(77,5 \%)$ de amostras positivas $(n=93)$ foi observada em crianças menores de cinco anos de idade. A maior concentração de casos positivos para o rotavírus ocorreu nos meses frios e secos dos quatro anos avaliados. Os genotipos de maior ocorrência foram: G1 (50,9\%), G4 (9,6\%), G9 (7,0\%), G2 (1,7\%), G3 (0,9\%), P[8] (71,9\%) e $\mathrm{P}[4](3,5 \%)$. P[8]G1 $(46,5 \%)$ e P[8]G4 $(9,6 \%)$ foram as associações de genotipos $P$ e $G$ mais 
encontradas. Infecções mistas, caracterizadas por estirpes de rotavírus com mais de um genotipo $\mathrm{G}$, $\mathrm{P}$ e amostras não-genotipadas foram observadas, respectivamente, em 8,8, 3,5 e em $16,7 \%$ das amostras. De forma semelhante ao que vem ocorrendo em várias partes do mundo a identificação do genotipo G9 em estirpes de rotavírus identificadas ao longo dos quatro anos do estudo ratifica a emergência desse genotipo também no Estado do Paraná, Brasil.

\section{REFERENCES}

Alfieri, A. A.; Leite, J. P. G.; Nakagomi, O.; Kaga, E.; Woods, P.; Glass, R. I. and Gentsch, J. R. (1996), Characterization of human rotavirus genotype $\mathrm{P}[8] \mathrm{G} 5$ from Brazil by probe hybridization and sequence. Archives of Virology, 141, 2353-2364.

Alfieri, A. F.; Alfieri, A. A.; Barreiros, M. A.; Leite, J. P. G. and Richtzenhain, L. J. (2004), G and P genotypes of group A rotavirus circulating in calves in Brazil, 1996-1999. Veterinary Microbiology, 99: (3-4), 167-173.

Boom, R.; Sol, C. J.; Salimans, M. M.; Jansen, C.L.; Wertheim-VAN Dillen, P. M. and VAN DER Noordaa, J. (1990), Rapid and simple method for purification of nucleic acids. Journal of Clinical Microbiology, 28: (3), 495-503.

Cardoso, D. D.; Soares, C. M.; Souza, M. B.; Azeredo, M. S.; Martins, R. M.; Queiroz, D. A.; Brito, W. M.; Mumford, V.; Racz, M. L. and Queiroz, D. A. (2003), Epidemiological Features of Rotavirus Infection in Goiânia, Goiás, Brazil, from 1986 to 2000. Memórias do Instituto Oswaldo Cruz, 98: (1), 25-29.

Cicirello, H. G.; Das, B. K.; Gupta, A.; Bhan, M. K.; Gentsch, J. R.; Kumar, R. and Glass, R. I. (1994), High prevalence of rotavirus infection among neonates born at hospitals in Delhi, India: predisposition of newborns for infection with unusual rotavirus. Pediatrics Infectious Diseases Journal, 13, 720-724.

Coluchi, N.; Munford, V.; Manzur, J.; Vazquez, C.; Escobar, M.; Weber, E.; Marmol, P. and Racz, M. L. (2002), Detection, subgroup specificity, and genotype diversity of Rotavirus strains in children with acute diarrhea in Paraguay. Journal of Clinical Microbiology, 40: (5), 1709-1714.

Cunliffe, N. A.; Gondwe, J.S.; Broadhead, R. L.; Molyneaux, M. E.; Woods, P. A.; Bresee, J. S.; Glass, R. I.; Gentsch, J. R. and Hart, C. A. (1999), Rotavirus $\mathrm{G}$ and $\mathrm{P}$ types in children with acute diarrhea in Blantyre, Malawi, from 1997-1998: predominance of a novel P [6] G8 strain. Journal of Medical Virology, 57: (3), 308-312.
Das, B. K.; Gentsch, J. R.; Cicirello, H. G.; Woods, P. A.; Gupta, A.; Ramachandran, M.; Kumar, R.; Bhan, M. K. and Glass, R. I. (1994) Characterization of rotavirus strains from newborns in New Dehli, India. Journal of Clinical Microbiology, 32, 1820-1822.

Desselberger, U. (2000), Emerging and re-emerging infectious diseases. The Journal of Infection, 40: (1), 3-15.

Fang, Z. Y.; Yang, H.; Qi, J.; Zhang, J.; Sun, L. W.; Tang, J. Y.; Ma, L.; Du, Z. Q.; He, A. H.; Xie, J. P.; Lu, Y. Y.; Ji, Z. Z.; Zhu, B. Q.; Wu, H. Y.; Lin, S. E.; Xie, H. P.; Griffin, D. D.; Ivanoff, B.; Glass, R. I. and Gentsch, J. R. (2002), Diversity of rotavirus strains among children with acute diarrhea in China: 19982000 surveillance study. Journal of Clinical Microbiology, 40, 1875-1878.

Gentsch, J. R.; Glass, R. I.; Woods, P.; Gouvea, V.; Gorziglia, M.; Flores, J.; Das, B. K. and Bhan, M. K. (1992), Identification of group A rotavirus gene 4 types by polymerase chain reaction. Journal of Clinical Microbiology, 30, 1365-1373.

Gentsch, J. R.; Woods, P. A.; Ramachandran, M.; Das, B. K.; Leite, J. P. G.; Alfieri, A. A.; Kunmar, R.; Bhan, M. K. and Glass, R. I. (1996), Review of G and $\mathrm{P}$ typing results from a global collection of rotavirus strains: implications for vaccine development. Journal of Infectious Diseases, 174: (1), S30-S36.

Gonzales-Ioza, M. R.; Polanco-Marin, G. G. and Puerto-Solis, M. (2000), Identificação de rotavírus associado ao sorotipo G2 em Yucatan, México. Revista da Sociedade Brasileira de Medicina Tropical, 33: (6), 553-557.

Gouvêa, V.; Santos, N. and Timenetsky, M. C. (1994a) VP4 typing of bovine and porcine group A rotaviruses by PCR. Journal of Clinical Microbiology, 32, 1333-1337.

Gouvea, V.; Santos, N. and Timenetsky, M. C. (1994b), Identification of bovine and porcine rotavirus $\mathrm{G}$ types by PCR. Journal of Clinical Microbiology, 32, 13381340.

Herring, A. J.; Inglis, N. F.; Ojeh, C. K.; Saodgrass, D. R. and Menzies, J. D. (1982), Rapid diagnosis of rotavirus infection by direct detection of viral nucleic acid in silver-stained polyacrylamide gels. Journal of Clinical Microbiology, 16, 473-477.

Jain, V.; Das, B. K.; Bhan, M. K.; Glass, R. I. and Gentsch, J. R. (2001), Great diversity of group A rotavirus strains and high prevalence of mixed rotavirus infection in India. Journal of Clinical Microbiology, 39, 3524-3529.

Kapikian, A. Z.; Hoshino, Y. and Chanock, R. M. (2001), Rotaviruses. In- Fields Virology, eds. Knipe, D. M. and Howlley, P. M., 4th edn. Lippincott Williams \& Wilkins, Philadelphia, pp. 1787-1833.

Kosek, M.; Bern, C. and Guerrant, R. L. (2003), The magnitude of the global burden of diarrheal disease from studies published 1992-2000. Bulletin of the World Health Organization, 81:(3), 197-204. 
Leite, J. P. G.; Alfieri, A. A.; Woods, P. A.; Glass, R. I. and Gentsch, J. R. (1996), Rotavirus G and P types circulating in Brazil: characterization by RT-PCR, probe hybridization, and sequence analysis. Archives of Virology, 141, 2365-2374.

Linhares, A. C.; Gabbay, Y. B.; Mascarenhas, J. D.; Freitas, R. B.; Flewett, T. H. and Beards, G. M. (1988), Epidemiology of rotavirus subgroups and serotypes in Belem, Brazil: a three-year study. Annales del Institut Pasteur/ Virologie, 139, 89-99.

Linhares, A. C.; Gabbay, Y. B.; Mascarenhas, J. D.; Freitas, R. B.; Oliveira, C. S.; Bellesi, N.; Monteiro, T. A.; Lins-Lainson, Z.; Ramos, F. L. and Valent, A. S. (1996), Immunogenicity, safety and efficacy of rhesus-human, reassortant rotavirus vaccine in Belém, Brazil. Bulletin of the World Health Organization, 74, 491-500.

Mascarenhas, J. D.; Arias, C. F.; Noriega, L. P.; Lopez, S.; Gusmão, R. H.; Gabbay, Y. B. and Linhares, A. C. (1997), Characterization of Rotavirus strains with unusual electrophoretic profiles. Memórias do Instituto Oswaldo Cruz, 92: (6), 771-774.

Mascarenhas, J. D.; Gusmão, R. H.; Barardi, C. R.; Paiva, F. L.; Simões, C. O.; Gabbay, Y. B.; Monteiro, T. A. and Linhares, A. C. (1999), Characterization of rotavirus $\mathrm{P}$ genotypes circulating among paediatric inpatients in Northern Brazil. Revista do Instituto de Medicina Tropical de São Paulo, 41: (3), 165-170.

Matsui, S. M.; Offit, P. A.; Vo, P. T.; Mackow, E. R.; Benfield, D. A.; Shaw, R. D.; Padilha-Noriega, L. and Greenberg, H. B. (1989), Passive protection against rotavirus-induced diarrhea by monoclonal antibodies to the heterotypic neutralization domain of VP7 and the VP8 fragment of VP4. Journal of Clinical Microbiology, 27, 780-782.

Parashar, U. D.; Bresee, J. S.; Gentsch, J. R. and Glass, R. I. (1998), Rotavirus. Emerging Infectious Diseases, 4: (4) 561-570.

Parashar, U. D.; Hummelman, E. G.; Bresee, J. S.; Miller, A. M. and Glass, R.I. (2003), Global illness and deaths caused by rotavirus disease in children. Emerging Infectious Diseases, 9: (5), 565-571.

Pereira, H. G.; Azeredo, R. S.; Leite, J. P. G.; Candeias, J. A.; Racz, M. L.; Linhares, A. C.; Gabbay, Y. B. and Trabulsi, J. R. (1983), Electrophoretic study of the genome of human rotaviruses from Rio de Janeiro, São Paulo and Pará. The Journal of Hygiene, 90: 117-125.

Pereira, H. G.; Azeredo, R. S.; Leite, J. P. G.; Andrade, Z. P. and Castro, L. (1985), A combined enzyme immunoassay for rotavirus and adenovirus. Journal of Virological Methods, 10: 21-28.
Pereira, H. G.; Linhares, A. C.; Candeias, J. A. and Glass, R. I. (1993), National laboratory surveillance of viral agents of gastroenteritis in Brazil. Bulletin of the Pan American Health Organization, 27, 224-233.

Pesavento, J. B.; Estes, M. K. and Prasad, B. V. (2003), Structural organization of the genome in rotavirus. InViral Gastroenteritis, eds. Desselberger U, Gray J. 1st edn, v.9. Elsiever Science, Amsterdam, pp. 115118.

Rahman, M.; Matthijnssens, J.; Nahar, S.; Podder, G.; Sack, D. A.; Azim, T. and Ranst, M. V. (2005), Characterization of a Novel P[25],G11 Human Group A Rotavirus. Journal of Clinical Microbiology, 43:(7), 3208-3212.

Rao, C. D.; Gowda, K. and Reddy, B. S. (2000), Sequence analysis of VP4 and VP7 genes of nontypeable strains identifies a new pair of outer capsid proteins representing novel $\mathrm{P}$ and $\mathrm{G}$ genotypes in bovine rotaviruses. Virology, 276: 104-113.

Ray, P. G. and Kelkar, S. D. (2004), Prevalence of neutralizing antibodies agains different rotavirus serotypes in children with severe rotavirus-induced diarrhea and their mothers. Clinical Diagnostic Laboratory Immunology, 11: (1), 186-194.

Santos, N. and Hoshino, Y. (2005), Global distribution of rotavirus serotypes/genotypes and its implication for the development and implementation of an effective rotavirus vaccine. Reviews in Medical Virology, 15: (1), 29-56.

Sattar, S. A.; Ijaz, M. K.; Johnson-Lussenburg, C. M. and Springthorpe, V. S. (1984), Effect of relative humidity on the airborne survival of rotavirus SA11. Applied and Environmental Microbiology, 47, 879881.

Villena, C.; El-Senousy, W. M.; Abad, F. X.; Pinto, R. M. and Bosch, A. (2003), Group A Rotavirus in sewage samples from Barcelona and Cairo: Emergence of unusual genotypes. Applied and Environmental Microbiology, 69: (7), 3919-3923.

Received: February 24, 2005; Revised: December 27, 2006; Accepted: December 28, 2007. 